\title{
Is Porter's Five Forces Framework Still Relevant? A study of the capital/labour intensity continuum via mining and IT industries
}

\author{
Diane Isabelle, Kevin Horak, Sarah McKinnon, Chiara Palumbo
}

\author{
" A horse never runs so fast as when he has other horses to catch up and outpace."
}

- Ovid

\begin{abstract}
Porter's Five Forces (P5F) framework, published in 1979, helps us to understand the attractiveness of an industry. The five competitive forces are: the threat of new entrants, the bargaining power of buyers, the bargaining power of suppliers, the threat of substitute products of services, and the rivalry among existing competitors. This framework has recently come under scrutiny and been called into question. To contribute to the debate, this paper investigates the relevance of Porter's framework by contrasting vastly different industries. The use cases consist of a resource-based, capital-intensive industry, the mining industry, and a knowledge-based, labor-intensive industry, the information technology industry. Drawing from research on Porter's Five Forces framework, and through an internationalization lens, the paper proposes a modified framework augmented with four additional forces. These additional forces are: the competitor's level of innovativeness, exposure to globalization, threat of digitalization, and industry exposure to de/regulation activities. These forces were added to capture the increased interconnectivity and complexity of businesses operating in the 21st century. The paper contributes to this body of knowledge by augmenting a popular framework and applying it to vital industrial sectors. The findings aim to incite researchers, managers, entrepreneurs and policymakers to go beyond the traditional five forces as a way to help monitor their business environment and enhance decision-making processes, particularly in a post-COVID-19 world.
\end{abstract}

\section{Introduction}

In 1979, Michael E. Porter published a seminal framework about competitive forces, the five forces framework, which quickly became the definitive tool to identify forces driving industry competition (Porter, 1979). The five forces - threat of new entrants, bargaining power of buyers, bargaining power of suppliers, threat of substitute products or services, and rivalry among existing competitors - were considered applicable to every industry, regardless of level of technology or economic development (Porter, 2008). The business world has become increasingly more global and complex since then, which is prompting a reappraisal of this highly popular managerial tool.

Without a doubt, among the most significant changes to the business world is globalization, which has intensified rapidly since the 1980s. Recent technological innovations and the presence of increasing numbers of people with international business experience have helped establish new foundations for internationalization (Oviatt \& McDougall, 2005) resulting in businesses further expanding their trade footprints. Even with the weakening of globalization lately due to geopolitics, economic isolationism, and the COVID-19 pandemic, economies around the world are highly integrated and industries interdependent. Globalization is clearly a key driver of internationalizing firms (Zucchella et al., 2007), which can be a gradual process, as per the Uppsala model (Johanson \& Vahlne, 1977), or accelerated (Rennie, 1993; Oviatt \& McDougall, 1994). Over the last decades, even small firms in their early lifecycle stage are increasingly driving international expansion.

In spite of some adjustments to Porter's Five Forces over the past 40 years, questions remain about its 


\section{Is Porter's Five Forces Framework Still Relevant? A study of the capital/labour intensity continuum via mining and IT industries Diane Isabelle, Kevin Horak, Sarah McKinnon \& Chiara Palumbo}

relevance in the 21 st century. Critics argue that Porter's Five Forces framework is too static, and hence omits changes in the competitive environment (Thyrlby, 1998; Grundy, 2006) such as the drivers of internationalization. Consider that back in 1979, information technology (IT) was viewed as a means of supporting the original five forces rather than as a distinct force. Nowadays, IT, or as often labelled "the tech industry", is a \$5.2USD trillion global market, and still growing at a fast pace (CompTIA, 2019).

In light of the above, the research questions for this paper are: Is the P5F framework still relevant in the 21st century's hypercompetitive business environment? Can the framework apply to vastly different industries such as a traditional resource-based capital-intensive industry, as well as a labour-intensive knowledge-based industry? Are additional forces also applicable to these industries?

The objective of this article is to explore the relevance of Porter's Five Forces (P5F) by contrasting the mining industry, a resource-based, capital-intensive industry, with the information technology industry, a knowledgeintensive industry. A comparison between these two industries at different ends of the capital-intensity continuum allows for a careful investigation of the contemporary relevance of P5F. Further, these two particular industries are crucial for Canada and many other countries in terms of economic development.

The paper's contributions are therefore threefold: First, adding to the management literature by building from research on $\mathrm{P} 5 \mathrm{~F}$ and internationalization theories to examine the relevance of the model to vastly different industries. Second, broadening the research on P5F by augmenting the framework with additional forces that are applicable to many industries today. Third, inciting managers, entrepreneurs, and policymakers to monitor the global business environment of specific industries beyond the traditional five forces to help avoid flawed decision-making.

\section{Literature Review}

We present a brief synthesis of the relevant literature related to P5F framework and internationalization.

\section{Porter's Five Forces (P5F)}

Porter introduced his five forces framework in 1979 as a way to understand an industry's attractiveness. His framework revolutionized the way managers and entrepreneurs analyze their industry's competitive environment by examining specific forces driving industrial competition. It has become one of the most popular business strategy tools.

The five forces are: the threat of new entrants, the bargaining power of buyers, the bargaining power of suppliers, the threat of substitute products or services, and the rivalry among existing competitors (Porter 1979). The first four forces determine the fifth force, competitive rivalry, which can be minimal or intense depending on the number and strength of competitors. The strength of each of the forces negatively impacts profitability. Importantly, Porter assumed these five forces were applicable to every industry, regardless of its level of technology, whether in a developed or emerging economy, and with or without government interventions (Porter, 2008). These assumptions are now coming under threat, or at least are once again being vigorously discussed. Figure 1 (below) illustrates the framework.

The continued popularity of this management tool in the academic and practitioner domains is evident. A cursory Google Scholar search of "Porter five forces" over the past five years yielded thousands of academic articles. Yet scholars nevertheless still argue about its relevance in today's globalized world. This creates an opportunity for the contribution of this research.

\section{Critiques of P5F}

In recent years, the P5F framework has come under fire. Scholars have raised several shortcomings. For example, Lee et al. (2012) argue that the framework is difficult to operationalize, while Narayanan and Fahey (2005) question the framework's validity. Some believe that the framework has already become frozen in time (Thyrlby, 1998; Grundy, 2006). Others point out that it has a specific emphasis on large organizations (Bruijl, 2018) and value chains over ecosystems (Keen \& Williams, 2013).

There are essentially three schools of thought on the criticisms of P5F. Researchers from the first school of thought believe that only minor adjustments are needed (Slater \& Olson, 2002). The second school argues for moderate changes to the forces in order to take into consideration such factors as time dynamics (Dulčić et al., 2012), not-for-profit organizations (Breedveld et al., 2006; Indiatsy et al., 2014), corporate social responsibility (Maxfield, 2008) collaboration and strategic alliances (Holm et al., 1996), and small businesses (Bruijl, 2018). A third school of thought 


\section{Is Porter's Five Forces Framework Still Relevant? A study of the capital/labour intensity continuum via mining and IT industries Diane Isabelle, Kevin Horak, Sarah McKinnon \& Chiara Palumbo}

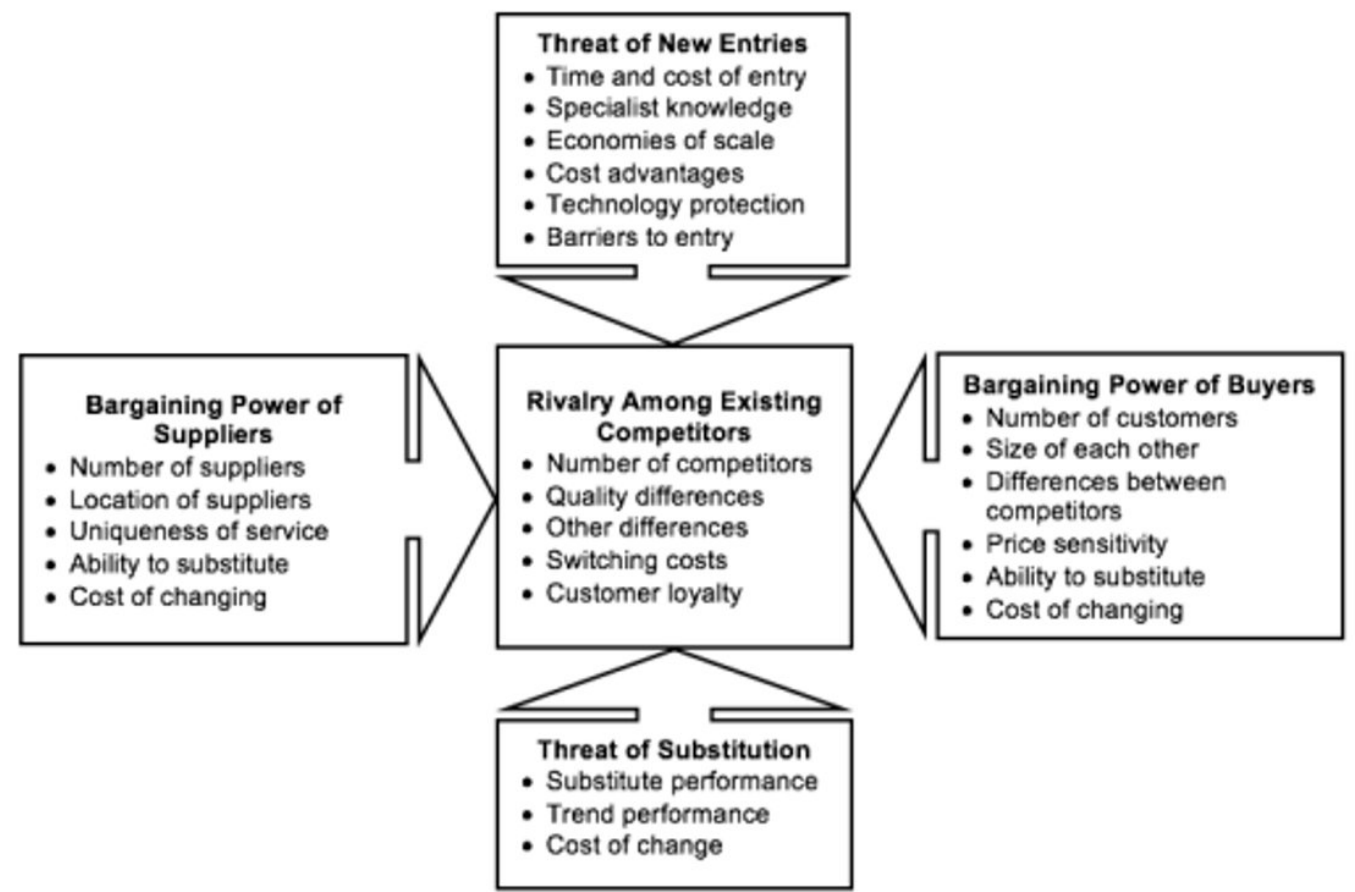

Figure 1. Porter's Five Forces framework (Porter, 1979)

argues for major adjustments to the framework (Narayanan \& Fahey, 2005; Lee et al., 2012) by either reconsidering the forces or combining the framework with alternative strategic frameworks, such as a resource-based view (Barney, 1991), using the so-called Delta model, which emphasizes the importance of attracting, satisfying, and retaining customers (Hax \& Wilde Ii, 2001), or with a Blue Ocean strategy, which is a first mover approach (Kim \& Mauborgne, 2005).

The vast majority of academics in the field consider that anywhere from medium to major adjustments to the framework are currently required. (Johnson, 2014). Wahlström (2019) notes that many companies do not go beyond the five forces to monitor their business environment. Nevertheless, the implementation of scenario-planning related to globalization, digital transformation, or sustainable development, in terms of their potential impacts to company operations, would also likely bring about critical knowledge and enhance business decision-making.

Downes (1997) has gained popularity among researchers who argue against P5F by proposing three additional forces driving industry competition to complement P5F: globalization, digitalization, and deregulation. Johnson (2014) added another force, the level of innovativeness. In earlier years, the level of innovativeness was considered an internal factor leading to a competitive advantage, but it now considered a vital external factor among forces driving industry competition (Bruijl, 2018). This research shows that the framework is indeed in need of major revisions, hence the purpose of this study.

\section{Internationalization theories}

At the time Porter published his P5F in the 1970s, internationalization was primarily conducted by multinational enterprises (MNEs). Past literature has outlined the need for a stage-based process to internationalization, which supports the idea that only large companies have the necessary resources to access international markets. Johanson and Vahlne's (1977) seminal Uppsala model advocated for a gradual process of internationalization via a series of incremental steps to enter geographically and culturally closer markets with low-risk modes of entry, then later to gradually enter more distant foreign markets. Since then, early and fast internationalization has picked up in pace, in particular with high-tech start-ups such as born-global (BGs) firms (Rennie, 1993) and international new ventures (INVs) (Oviatt \& McDougall, 1994), enabled by lower communication and transportation costs. There has also been extensive research done on the early internationalization of firms operating in technologyintensive industries, as well as other industries (Madsen 


\section{Is Porter's Five Forces Framework Still Relevant? A study of the capital/labour intensity continuum via mining and IT industries Diane Isabelle, Kevin Horak, Sarah McKinnon \& Chiara Palumbo}

\& Servais, 1997; Cavusgil \& Knight, 2015; Del Sarto et al., 2019). Interestingly, early internationalization, which is considered riskier, is often associated with experienced entrepreneurs who might have used the Uppsala model before founding their born-global firm (Neubert, 2017). A business internationalization lens is considered particularly relevant to our investigation of $\mathrm{P} 5 \mathrm{~F}$.

\section{Comparative Analysis of the Mining Industry and the Information Technology Industry}

This section presents an overview of two selected industries to highlight their specific characteristics, as well as global data and trends related to these industries. The purpose is to apply the P5F to these industries to answer our above research questions.

\section{Overview of the mining industry}

The mining industry is a resource-based, capitalintensive industry, which explains why we selected that industry to contrast it with IT, a knowledge-based industry. Operating in the exploration, extraction, and processing of natural resource materials, the mining industry has deep historic roots as a player in global business, economics, and trade. The revenue of the top 40 global mining companies was 683 billion USD in 2018 (Statista, 2019). The mining sector delivers the raw materials to support the so-called "fourth industrial revolution" (Schwab, 2015; PWC, 2019). In Canada, the total value of mineral production in 2018 was $\$ 47$ billion CAD. Canada is the global leader in the production of potash and ranks among the top five global producers for cadmium, cobalt, diamonds, gemstones, gold, graphite, indium, nickel, niobium, platinum group metals, salt, titanium concentrate, and uranium. Canada also accounts for a significant proportion of the global production of primary aluminum from imported bauxite and alumina (NRCan, 2020).

As a resource-based industry, mining demands a high level of international involvement. The metals and minerals are only found in specific geological areas, thus confining operations to those locations, before being distributed and sold around the globe. It thereby requires an international network in order to function. The general operations of mining firms consist of four lifecycle stages: exploration, development, production, and closure (Natural Resource Governance Institute, 2015). While each individual mine site will undergo this lifecycle, the large costs associated with initial testing, exploration, and construction has encouraged some firms to expand operations through merger and acquisition activity. We often observe multinational firms absorbing smaller and more regional firms into their operations. Internationalization is thus an already existing key factor for mining companies that wish to succeed within the industry. Significant industry players, therefore, consist mainly of large private or state-sponsored firms that oversee multiple international operations. These international new venture companies are usually headquartered in one nation, while operating mines exclusively outside of their domestic market. There is also a mixture of smaller regional and small-scale international firms (Natural Resource Governance Institute, 2015).

Taken as a whole, the mining industry, and its role as a supplier of base materials to diverse sectors, therefore lends itself to be substantially influenced and impacted by macroeconomic trends and movements in the global economy. Commodities markets are highly cyclical, with largely recognizable periods of rise and decline occurring over a period of years. As producers of mostly non-differentiated products, mining companies are particularly vulnerable to the behaviour of this cycle (Collings, 2013). Further, as commodities traded on the global market are often priced in US dollars, changes in the actual or perceived strength of the American economy, as well as shifts in USD value relative to other currencies, directly influence commodities sellers, resulting in an inverse relationship between commodities prices and USD. Foreign exchange risk, depending on the host nation's taxation and regulations regime, is a relevant consideration for any international ventures, and even more so for the mining industry due to the diverse geographic presence of its players.

\section{Mining industry trends}

Trends and issues facing the mining industry include trade wars, geopolitical crises, and climate change. The industry provides carbon-based raw materials such as coal, and is a substantial creator of CO2 emissions. China comprises 10 companies out of the Global Top 40 mining companies, while Australia, the UK, and South Africa have 7, Canada has 6, with the balance spread among the USA, Russia, Brazil, Switzerland, Poland, Indonesia, Japan and Mexico (PWC, 2019). Mergers and acquisitions in the mining industry have recently picked up. Safety, however, remains a challenge, and thus so does the industry's image. Investors and stakeholders continue to be concerned that the mining industry is lagging behind regarding new factors that have not traditionally been the industry's focus, in particular dealing with greenhouse gas emissions, the greening of 


\section{Is Porter's Five Forces Framework Still Relevant? A study of the capital/labour intensity continuum via mining and IT industries Diane Isabelle, Kevin Horak, Sarah McKinnon \& Chiara Palumbo}

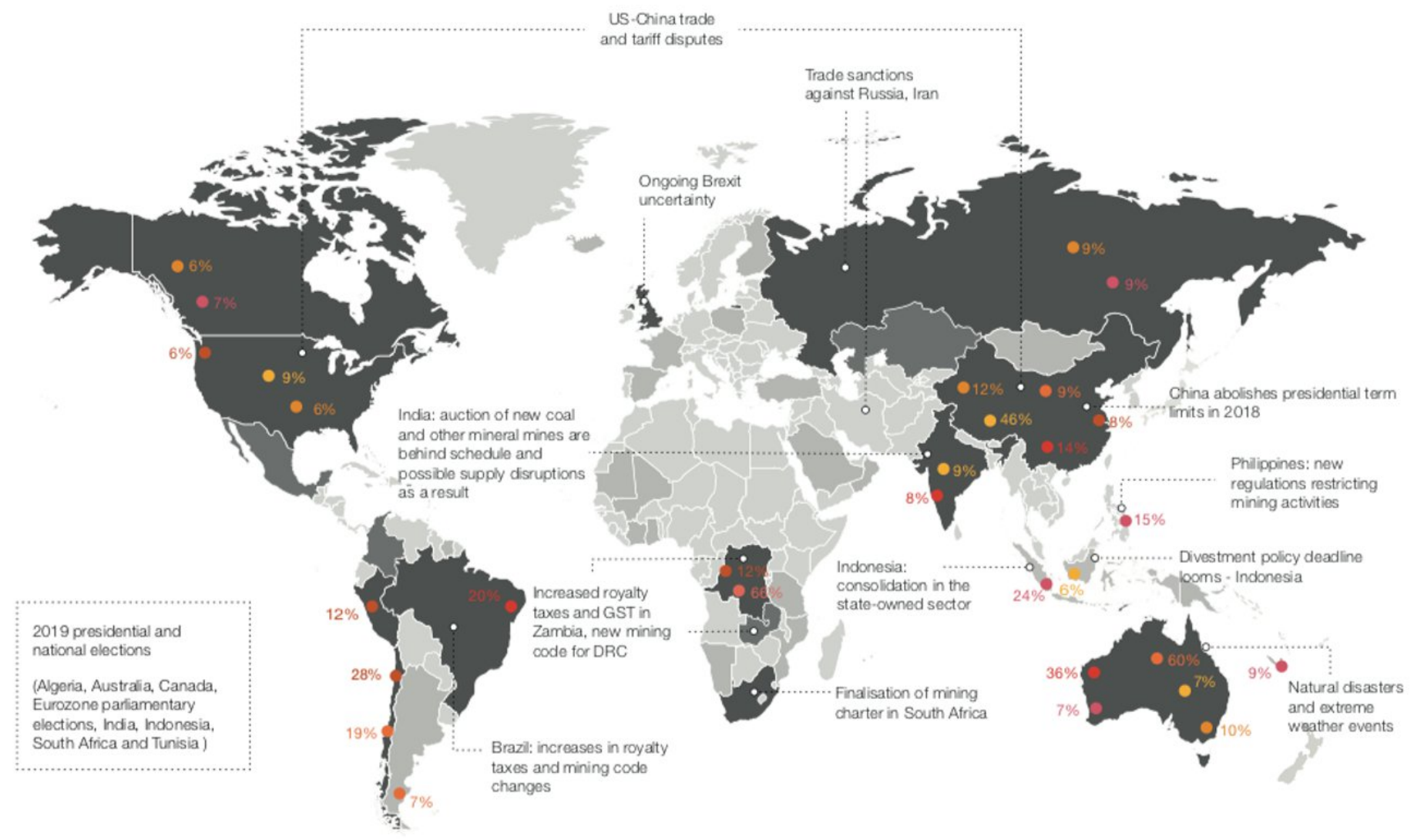

Top 40 representation
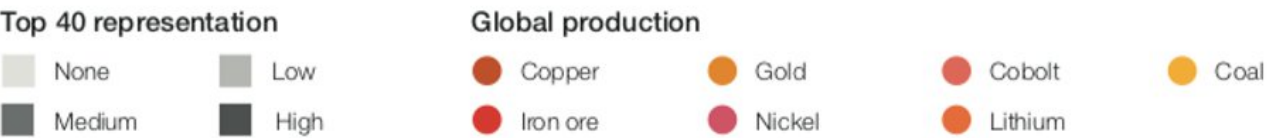

Figure 2. Top 40 reach and external market drivers (PWC, 2019)

the supply chain, and investing in technology that includes digital innovation (Kusi-Sarpong et al., 2015; PWC, 2019). Figure 2 below illustrates the Top 40 reach and external market drivers.

\section{Overview of the Information Technology (IT) industry}

IT is a knowledge-based industry that has developed rapidly since the 70 s, such that it is now ubiquitous and pervasive. The term 'information technology' (IT) is used to describe a wide variety of aspects relating to information systems based on computers (Economy Watch, 2010). This broad definition includes areas ranging from software development and hardware, to the design, implementation, study, and development of IT management systems, as well as telecom services (CompTIA 2019; Economy Watch, 2010). One key differentiator from the mining industry is that IT is inherently knowledge-based, meaning that much of its characteristics are derived from the labour force
(CompTIA 2019).

Based on research by the Computing Technology Industry Association (CompTIA, 2019), the global IT industry is already worth $\$ 5.2$ trillion USD (2019), and one of the most significant contributors to GDP growth in many countries. Approximately $\$ 1.7$ trillion USD (33\% of the industry) is transacted in the USA. Among global regions, China has clearly established itself as a major player, while western Europe remains a significant contributor. In Canada, the sector is represented under the label "information and communications technologies” (ICT). In 2018, ITC accounted for \$193B CAD in revenue, contributing to $4.5 \%$ of GDP, and $\$ 23 \mathrm{~B}$ CAD in exports, or $15 \%$ of total Canadian exports (Government of Canada, 2019). The sector, which provides 1 million direct and indirect jobs, is considered the engine of growth in Canada, and is the largest private-sector performer in R\&D. Of note, $86 \%$ of the 


\section{Is Porter's Five Forces Framework Still Relevant? A study of the capital/labour intensity continuum via mining and IT industries Diane Isabelle, Kevin Horak, Sarah McKinnon \& Chiara Palumbo}

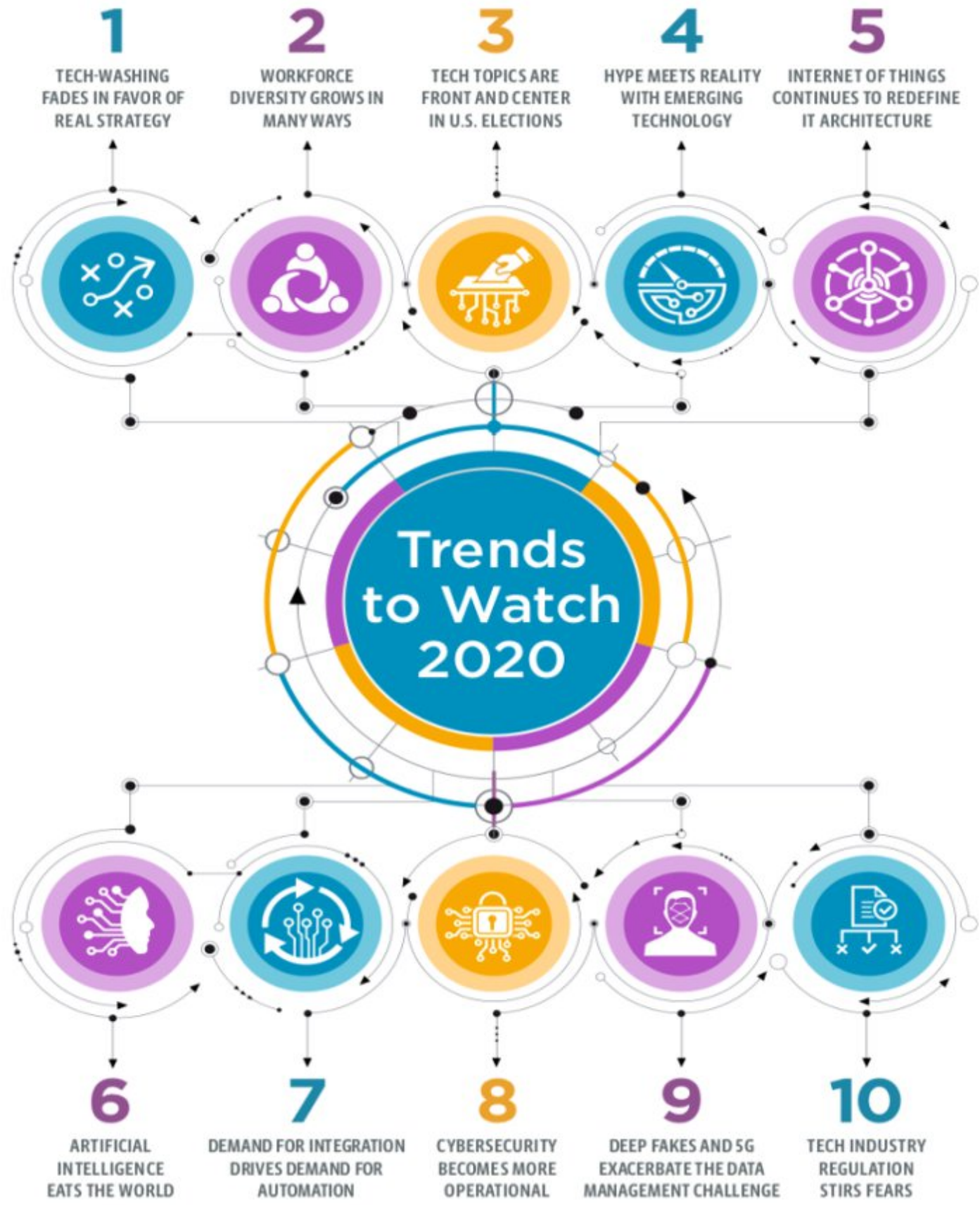

Figure 3. Ten trends to watch for in 2020 (CompTIA, 2019)

37,000 firms in the sector are small businesses (ITAC, 2020).

\section{IT industry trends}

CompTIA (2019) has identified 10 trends to watch for in 2020 and beyond, which is illustrated in Figure 3. This section considers some of them in the context of this paper. Tech-washing and marketing hyperbole will not allow growth. Rather, sound digital transformation business models are needed for large and small firms to flourish. Further, businesses will be more strategic in their approach to integrate technology into their market offerings. As for hype-meeting-reality with emerging technologies, significant gains are expected this year from emerging tech adoption. However, adoption rates have been very slow across several new trends, in spite 


\section{Is Porter's Five Forces Framework Still Relevant? A study of the capital/labour intensity continuum via mining and IT industries Diane Isabelle}

of industry hype, as some companies moved too quickly into a new technology trend, and had to face harsh realities of immature or unready markets.

That said, Internet of Things (IoT) and artificial intelligence (AI) are two trends gaining significant traction and beginning to reach critical mass, especially since cloud computing acts as a key enabler for AI by lowering the barrier for software development and distribution (Hudson, 2017; Groher et al., 2019). Also enabled by cloud systems, firms are now actively integrating platforms, applications, and data, and starting to move deeper into complex automation. Among other trends, cybersecurity is expected to shift from being seen as merely a component of IT, to instead being a critical business function itself. The video and voice forgery software of "deep fakes" has the potential to wreak havoc on society, personal lives, politics and beyond. Such misuses of IT will proliferate in the digital era and require sophisticated data management systems to handle exponentially larger data volumes, enabled by newly rolled-out 5G networks (CompTIA, 2019; Westerlund, 2019). The potential for increased government regulation around such issues as privacy, data protection, election interference, and others is an obvious concern as the tech industry matures and grows more complex.

The technology ecosystem in Canada is currently considered as being more self-sustaining than ever before, driven by talent, strong infrastructure, and committed government support. Further, the following Canadian trends bode well for the creation and retention of strong tech firms: greater ability to retain ownership control of the company during financing phases, as well as growing availability of tech talent, partly due to colleges and universities graduating students with needed skills and immigration policies (Aten et al., 2016).

\section{Findings}

Contrasting the mining and IT industries with the original Porter's Five Forces Framework

The purpose of this research is to apply P5F to two industries positioned at different ends of the capitallabor intensity continuum. Doing so provides fertile ground to explore the continued relevance of the P5F framework given today's complex and global business environment. Table 1 summarizes a comparison of the original P5F (1979) between the mining industry and the IT industry.

\section{Augmented Porter's Five Forces}

Based on prior research and this analysis, we argue that the original P5F framework no longer meets the more complex needs of operating in the 21st century, and could lead to flawed decision-making processes nowadays. Therefore, drawing from the literature that proposes changes to the framework, in particular the work of Downes (1997) and Johnson (2014), a revised framework is presented in this study. This augmented framework is made to be applicable not only to the selected mining and IT industries in this paper, but more broadly to both capital-intensive as well as knowledge-intensive industries, meaning industries along the capital-labor intensity continuum. Figure 4 highlights the proposed augmented P5F.

\section{Threat of digitalization}

While there is no generally accepted definition of "digitalization", the term refers to a technology-induced transformation process with its goal to improve a business' flexibility, agility, and responsiveness, by aligning operations, strategy, business processes, and organizational as well as IT structures (Holotiuk \& Deimborn, 2017). In contrast, the term "digitization" carries a narrower scope of transforming analogous information into a digital representation, for example, books, journals, documents, or archives (Legner et al., 2017). The new force proposed for the augmented P5F focuses on the impacts of increased digitalization on an industry. The need for this dimension stems from a larger observation that firms no longer only face competition within their own industry, but also across industries (Downes, 1997; Neubert, 2018). This dimension can be measured by looking at four elements of digitalization in an industry: infrastructure (sophistication of existing IT technology), digital input (extent of digital processes in the procurement stage of the business), digital processing (degree to which processes are integrated, both internally and with external partners), and digital output (importance of digital processes in the sales function) (Friedrich, 2011; Johnson, 2014). The important observation along this dimension is that the better digitalized an industry is, the fiercer the competition is expected to be within that industry.

\section{Competitors' level of Innovativeness}

The dimension of innovativeness, previously considered as one of many resources a firm possesses to create a competitive advantage, is now becoming a source of competitive advantage. Studies have shown that the presence of foreign competitors in a market and the 


\section{Is Porter's Five Forces Framework Still Relevant? A study of the capital/labour intensity continuum via mining and IT industries Diane Isabelle, Kevin Horak, Sarah McKinnon \& Chiara Palumbo}

likelihood of a given firm to pioneer innovation grow in tandem (Johnson, 2014). In today's fast-paced IT sector, product life cycles are continuously shrinking, therefore firms must increase their speed of innovation to remain relevant. To measure the attractiveness of an industry in this dimension, a company should monitor the number of patents registered in that industry or market. Likewise with the Intellectual Property Index (IPI), as patents can either encourage or discourage innovation, depending on certain present market conditions. An industry is particularly attractive for a company to grow in if the number of patents and the IPI are both low, as it is thought that a competitive advantage can be achieved relatively easily in that environment (Jalles, 2010).

Table 1. Porter's Five Forces applied to mining and IT industries

\begin{tabular}{|c|c|c|}
\hline Force & Mining Industry & IT industry \\
\hline $\begin{array}{l}\text { Threats of New } \\
\text { Entrants }\end{array}$ & $\begin{array}{l}\text { LOW } \\
\text { - Highly capital-intensive } \\
\text { - Existing firms absorbing smaller players } \\
\text { limits the emergence of new players. } \\
\text { - Highly volatile commodities market, } \\
\text { strict legal requirements, and } \\
\text { environmental regulations. } \\
\text { - Competition largely a battle between } \\
\text { those already present }\end{array}$ & $\begin{array}{l}\text { HIGH } \\
\text { - Low barriers to entry. } \\
\text { - Firms can compete globally } \\
\text { with little to no physical } \\
\text { presence. } \\
\text { - Entry of firms from outside of } \\
\text { the technology sector. } \\
\text { - Digitally-based business models } \\
\text { are much less capital intensive } \\
\text { and more easily scalable. }\end{array}$ \\
\hline $\begin{array}{l}\text { Bargaining power } \\
\text { of buyers }\end{array}$ & $\begin{array}{l}\text { MODERATE } \\
\text { - Minimal product differentiation. } \\
\text { - Demand and power held by buyers that } \\
\text { are dependent upon segments and } \\
\text { varieties of end uses - automotive, } \\
\text { construction, manufacturing, and } \\
\text { engineering represent the largest buyers. } \\
\text { - Size of a buyer lends them a certain } \\
\text { degree of power, but tempered through } \\
\text { the use of long-term contracts with } \\
\text { mining firms. } \\
\text { - Pricing advantages of one geographic } \\
\text { region over another derived largely } \\
\text { through currency behaviour. }\end{array}$ & $\begin{array}{l}\text { HIGH } \\
\text { - Many options for consumers to } \\
\text { choose from due to large amount } \\
\text { of IT firms and easy access to } \\
\text { information. } \\
\text { - High pressure placed on IT } \\
\text { firms to satisfy ever evolving } \\
\text { expectations for the digital } \\
\text { customer experience. } \\
\text { - Pressure on industry to pioneer } \\
\text { leading \& innovative business } \\
\text { solutions. }\end{array}$ \\
\hline $\begin{array}{l}\text { Bargaining power } \\
\text { of suppliers }\end{array}$ & $\begin{array}{l}\text { Two separate supplier sources: } \\
\text { 1) LOW: Specialization required to } \\
\text { service the mining industry ties suppliers } \\
\text { closely with the mining companies they } \\
\text { do business with. } \\
\text { 2) HIGH: Land ownership and the } \\
\text { estimated reserves held within that land } \\
\text { means significant power over mining } \\
\text { companies. }\end{array}$ & $\begin{array}{l}\text { HIGH } \\
\text { The notion of supplier is } \\
\text { expanding: } \\
\text { - In a sharing economy, suppliers } \\
\text { can use their high bargaining } \\
\text { power to slow down disruptive } \\
\text { models. } \\
\text { - Suppliers can be government } \\
\text { regulators, supplying the } \\
\text { industry with critical permits and } \\
\text { licenses. E.g. Uber, Airbnb } \\
\text { - Human resources supply } \\
\text { challenge: finding and retaining } \\
\text { employees in the IT sector is } \\
\text { difficult } \\
\text { - Other suppliers such as data } \\
\text { aggregators enjoy immense } \\
\text { bargaining power over firms } \\
\text { given their expertise. }\end{array}$ \\
\hline
\end{tabular}




\section{Is Porter's Five Forces Framework Still Relevant? A study of the capital/labour intensity continuum via mining and IT industries Diane Isabelle, Kevin Horak, Sarah McKinnon \& Chiara Palumbo}

Table 1. Porter's Five Forces applied to mining and IT industries (cont'd)

\begin{tabular}{|c|c|c|}
\hline $\begin{array}{l}\text { Threat of } \\
\text { substitution }\end{array}$ & $\begin{array}{l}\text { LOW } \\
\text { - In spite of some substitution (plastics, } \\
\text { aluminum) across industries, metals } \\
\text { remain largely irreplaceable. } \\
\text {-Greater metal recycling efforts } \\
\text { represents a minimal threat. } \\
\text { - Greater threats lie between metal } \\
\text { segments, other metals, and synthetic } \\
\text { materials replacing each other in reaction } \\
\text { to industry demand and changing cost } \\
\text { pressures. }\end{array}$ & $\begin{array}{l}\text { HIGH } \\
\text { - Ease of doing business } \\
\text { internationally } \\
\text { - Substitute products can be } \\
\text { digital or hybrid. } \\
\text { - Low switching costs. } \\
\text { - Emergence of digital } \\
\text { marketplaces }\end{array}$ \\
\hline $\begin{array}{l}\text { Rivalry among } \\
\text { existing } \\
\text { competitors }\end{array}$ & $\begin{array}{l}\text { HIGH } \\
\text { - Highly competitive landscape with a mix } \\
\text { of powerful multinational companies, } \\
\text { large state sponsored operations, and } \\
\text { SMEs. } \\
\text { - Scalability of mining operations and } \\
\text { resulting cost-savings favours the } \\
\text { creation and growth of larger companies, } \\
\text { either through organic expansion or } \\
\text { acquisitions. } \\
\text { - Huge costs associated with exploration, } \\
\text { development and financing of new mines. } \\
\text { - Cyclical process of market behaviour } \\
\text { and high cost of exiting the industry lock } \\
\text { existing firms within the sector. } \\
\text { - Competitive firms either specialize } \\
\text { within one location or specific metal, or } \\
\text { seek diversification in product or } \\
\text { geography. } \\
\text { - Younger players seek out more niche } \\
\text { fields or operate mines in more obscure } \\
\text { locations. }\end{array}$ & $\begin{array}{l}\text { HIGH } \\
\text { - Rivalry among firms is } \\
\text { exacerbated by the rise of digital } \\
\text { technologies and e-business } \\
\text { coupled with the comparative } \\
\text { low-cost of business models. } \\
\text { - Companies no longer required } \\
\text { to own their physical } \\
\text { infrastructures. } \\
\text { - Large firms have financial } \\
\text { resources to invest in or acquire } \\
\text { innovative companies, thus giving } \\
\text { them a competitive edge in the } \\
\text { market. } \\
\text {-Increased coopetition }\end{array}$ \\
\hline
\end{tabular}

\section{Exposure to Globalization}

This dimension is grounded by the notion that for successful internationalization firms must manage farreaching networks of partners and develop long-lasting relationships with their clients, regardless of location. This dimension can be measured by looking at the rate of a country's tax increases and government expenditure (countries with a lower rate of government consumption are generally more globalized), the index of capital account openness, and the level of foreign direct investment (Johnson, 2014). It is argued that firms should weigh all of these factors equally as they can have a profound effect on industry/market viability.

\section{Industry exposure to de/regulation activities}

The deregulation dimension emerged from an observation that government influence in certain industries has dramatically shrunk over the last few decades. As industries become deregulated, they are more conducive to unimpeded business operations that are controlled and guided by the free market. However, this dimension is challenging to measure, as the level of deregulation depends largely on the sitting government, their decisions, and the political context at the current moment (Johnson, 2014).

However, a nuanced approach involving industry exposure to de/regulation activities is presented here. Prior research (Downes, 1997; Johnson, 2014) added deregulation as a force to P5F, citing a sharp decrease in government regulations in industries such as telecommunications, banking, airlines, and utilities in the USA and Europe. These studies were primarily based in the 1990s, a decade which experienced a reduction in regulations owing to a variety of factors. However, we have now entered an era of increased 


\section{Is Porter's Five Forces Framework Still Relevant? A study of the capital/labour intensity continuum via mining and IT industries Diane Isabelle, Kevin Horak, Sarah McKinnon \& Chiara Palumbo}

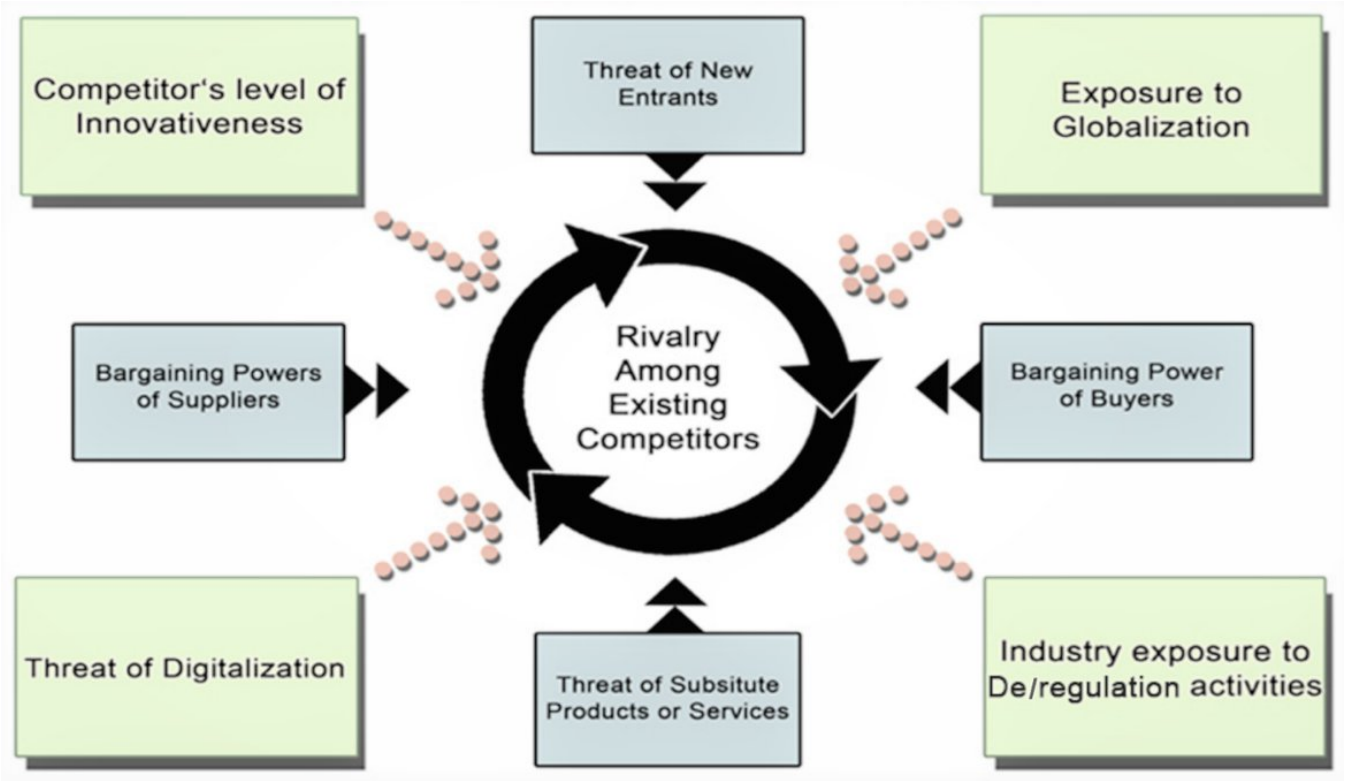

Figure 4. Proposed Augmented Porter's Five Forces Model

government regulations, be it related to climate change, anti-competitive business practices, health and safety, information privacy, and currently COVID-19. These regulations, at times, are introduced in a haphazard fashion. Consequently, we augment this force by adding both regulation as well as deregulation activities that firms must consider in order to analyze their industry and reduce their exposure to regulation and deregulation.

\section{Discussion and Conclusion}

\section{Theoretical implications}

We revisited Porter's Five Forces framework published in 1979 with the following research questions: Is the P5F framework still relevant in the 21st century's hypercompetitive business environment? Can the framework apply to vastly different industries such as a resource-based, capital-intensive industry, as well as a knowledge-based labour-intensive IT industry? Are additional forces proposed in the literature also applicable to these industries?

Prior research has proposed modifications to P5F since Porter's time. No research is known to have been conducted that actually corroborates the proposed additional forces. Further, no studies have contrasted resource-based, capital-intensive industries with knowledge-based, labor-intensive industries using an augmented P5F. Nor have studies attempted to apply an internationalization theoretical lens to the P5F framework.

The paper has demonstrated that in this era of internationalization, global value chains, a relentless pace of innovation, and changing regulatory environments, additional forces are applicable to both capital and labor-intensive industries. The paper also proposes a modified deregulation force to consider both regulation and deregulation. Furthermore, it contributes to an existing body of knowledge by highlighting the importance of critiquing and updating research frameworks, and applying them to industrial sectors that are vital to many countries.

\section{Managerial implications}

The key managerial implications from this research are as follows:

- The exposure to additional forces than P5F is now a constant reality in the IT industry. Consider that in Canada, only a third of small businesses operate on ecommerce platforms. Of these, half are facing challenges dealing with complex trade procedures, regulations, and lack of necessary resources to hire digital and international business specialists, which impedes their internationalization efforts and competitiveness. Digitalization offers plenty of opportunities to increase effectiveness, even though digital implementation can be significantly challenging. The mining industry has been comparatively slow in adopting digital technologies 


\section{Is Porter's Five Forces Framework Still Relevant? A study of the capital/labour intensity continuum via mining and IT industries Diane Isabelle, Kevin Horak, Sarah McKinnon \& Chiara Palumbo}

(Lakshmanan et al., 2019). Yet this industry is facing several challenges that new technologies, for instance, combining big data together with other technologies such as automation, have the potential to address (Qi, 2020). Fortunately, prior research has validated the significant impact of digitalization on internationalization (Neubert, 2018), and gives a positive finding that should motivate firms to embark more deeply on a path that reaps benefits and increases their global competitiveness.

- Whether in resource or labor-intensive industries, firms should monitor their competitors' level of innovativeness, particularly given the short length of product life cycles often driving industry competition. For instance, companies should monitor the number of patents and trademarks registered in an industry or market (Jaffe, 2010; Gotsch \& Hipp, 2014). In the mining industry, implementation of new technologies such as IoT, artificial intelligence, drones, thermal technology, and deep-sea mining, among others, could replace older methods for exploration, inspection and extraction (Dehran et al., 2018; Visser et al., 2019).

- It is crucial that firms closely monitor changes in regulation and deregulation, as well as increasing their advocacy role, given that many countries, including Canada, have now entered a period of increased regulation.

Governments of many countries are enacting new rules and regulations that industries are being asked to comply with. Examples include regulation that affects actors in the sharing economy, such as Uber and Airbnb, the General Data Protection Regulation (GDPR) in the EU that affects the IT industry, and the new Canadian Impact Assessment Act (CIAA) in the mining industry. However, there are various ways that new rules and regulation could also further the advancement of industries. For instance, rare-earth minerals represent another area where the traditional P5F is inadequate for the 21st century. Rare earth minerals are increasingly needed for electric cars, solar panels, and wind turbines, as well as other high-tech and military products. As a global mining powerhouse, new regulations in Canada could ensure that the country becomes a key player in the global EV battery supply chain. Moving in that direction, Canada and the USA are cooperating to reduce their reliance on China, which could control supply chain governance given that it has the largest share of the world's rare-earth mineral reserves. Canada is also working on a national rare-earth strategy (NRCan, 2020), with initiatives that will support the mining industry.

Experience shows that competitive landscapes can change very quickly with unforeseen situations, as evidenced with the COVID-19 global pandemic. Currently, Canadian mining firms, most of which operate mines around the world, are grappling with the pandemic and are facing the impacts of a potential global recession. Likewise, the IT industry is impacted by the pandemic. In both IT and mining industries, like in most industries, recovery from the pandemic will require massive changes to business models, innovativeness, rapid adoption of digital technologies and automation, and increased resiliency to succeed in whatever becomes the "new normal". These realities further stress the importance of our augmented P5F to appreciate rapidly evolving and globally competitive landscapes.

\section{Limitations and future research areas}

A limitation of this study is its focus on the mining and IT industries, although the findings should be generalizable to other similar industries, given previous applications of P5F. Nonetheless, our findings offer avenues for future investigations in other industries. Further, additional studies could apply our augmented P5F in a variety of industrial and geographic contexts. It is hoped that this revised and updated framework will incite researchers, managers, entrepreneurs, and policymakers to better understand business environments beyond the traditional five forces, as a way to enhance their decision-making processes in this turbulent business environment. Thorough analyses and monitoring of forces will in one way or another continue to be particularly crucial in a post-COVID-19 world, owing to greater social and economic uncertainties and with the expectation of accelerated adoption of technological innovations by several key industries to help ensure survival and prosperity. 


\section{Is Porter's Five Forces Framework Still Relevant? A study of the capital/labour intensity continuum via mining and IT industries Diane Isabelle, Kevin Horak, Sarah McKinnon \& Chiara Palumbo}

\section{References}

Aten, K., Nardon, L., \& Isabelle, D.A. 2016. Making sense of foreign context: Skilled migrant's perceptions of contextual barriers and career options. International Journal of Cross-Cultural Management, 16(2): 191-214.

Barney, J. 1991. Firm resources and sustained competitive advantage. Journal of Management, 17(1): 99-120.

Breedveld, E.J., Meijboom, B.R., \& de Roo, A.A. 2006. Labour supply in the home care industry: A case study in a Dutch region. Health Policy, 76(2):144-155. doi: http://dx.doi.org/10.1016/j.healthpol.2005.05.007

Bruijl, G.H.T. 2018. The Relevance of Porter's Five Forces in Today's Innovative and Changing Business Environment. SSRN 3192207.

Cavusgil, S. T., \& Knight, G. 2015. The born global firm: An entrepreneurial and capabilities perspective on early and rapid internationalization. Journal of International Business Studies, 46(1): 3-16.

CompTIA. 2019. IT Industry Outlook 2020. https://comptiacdn.azureedge.net/webcontent/docs /default-source/research-reports/comptia-itindustry-outlook-2020.pdf?sfvrsn=8869ad68_0

Dehran, S., Agrawal, P., \& Midha, P. 2018. Digital Applications in Metals and Mining Industry. American Journal of Operations Management and Information Systems, 3(1): 33-37.

Del Sarto, N., Di Minin, A., Ferrigno, G., \& Piccaluga, A. 2019. Born global and well educated: start-up survival through fuzzy set analysis. Small Business Economics: $1-19$.

https://doi.org/10.1007/s11187-019-00238-6

Downes, L. 1997. Beyond Porter. Context Magazine. http://www.mbatools.co.uk/Articles/BeyondPorter.p df

Dulčić, Ž., Gnjidić, V., \& Alfirević, N. 2012. From Five Competitive Forces to Five Collaborative Forces: Revised View on Industry Structure-firm Interrelationship. Procedia - Social and Behavioral Sciences, 58(0): 1077-1084.

http://dx.doi.org/10.1016/j.sbspro.2012.09.1088

EconomyWatch. 2010. IT Industry. Information Technology Industry.

http://www.economywatch.com/business-andeconomy/information-technology-industry.html.

Friedrich, R., Le Merle, M., Grone, F., \& Koster, A. 2011. Measuring industry digitization: Leaders and laggards in the digital economy. Booz \& Co., London.

Gotsch, M., \& Hipp, C. 2014. Using Trademarks to Measure Innovation in Knowledge-Intensive Business Services. Technology Innovation Management Review, 4(5): 18-30.

http://doi.org/10.22215/timreview/790

Government of Canada. 2019. Canadian ICT sector profile 2018.

https://www.ic.gc.ca/eic/site/ict-

tic.nsf/eng/h_it07229.html

Groher, W., Rademacher, F.-W., \& Csillaghy, A. 2019. Leveraging AI-based Decision Support for Opportunity Analysis. Technology Innovation Management Review, 9(12): 29-35.

http://doi.org/10.22215/timreview/1289

Grundy, T. 2006. Rethinking and reinventing Michael Porter's five forces model. Strategic Change, 15(5): 213-229.

doi: $10.1002 /$ jsc.764

Hax, A., \& Wilde II, D. 2001. The Delta Model discovering new sources of profitability in a networked economy. European Management Journal, 19(4): 379-391.

http://dx.doi.org/10.1016/S0263-2373(01)00041-X

Holm, D.B., Eriksson, K., \& Johanson, J. 1996. Business networks and cooperation in international business relationships. Journal of International Business Studies: 1033-1053.

Holotiuk, F., \& Beimborn, D. 2017. Critical Success Factors of Digital Business Strategy. 13th International Conference on Wirtschaftsinformatik, St. Gallen, Switzerland.

Hudson, D. 2017. Value Propositions for the Internet of Things: Guidance for Entrepreneurs Selling to Enterprises. Technology Innovation Management Review, 7(11): 5-11.

http://doi.org/10.22215/timreview/1116

Indiatsy, C.M., Mwangi, M.S., Mandere, E.N., Bichanga, J.M., \& George, G.E. 2014. The application of Porter's five forces model on organization performance: A case of cooperative bank of Kenya Ltd. European Journal of Business and Management, 6(16): 75-85.

ITAC. 2020. Industry snapshot. https://itac.ca/our-industry-our-profile/.

Jalles, J.T. 2010. How to measure innovation? New evidence of the technology-growth linkage. Research in Economics, 64(2): 81-96.

Johanson, J. \& Vahlne, J.-E. 1977. The internationalization process of the firm: a model of knowledge development and increasing foreign market commitments. Journal of International Business Studies, 8(1): 23-32.

Johnson, M.L.S.L.F. 2014. The 5 Competitive Forces Framework in a Technology Mediated Environment. Do these forces still hold in the industry of the 21st century? University of Twente. http:/ / essay.utwente.nl/66196/1/Johnson_BA_MB.pd f.

Keen, P., \& Williams, R. 2013. Value architectures for digital business: Beyond the business model. MIS Quarterly, 37(2): 642-647. 


\section{Is Porter's Five Forces Framework Still Relevant? A study of the capital/labour intensity continuum via mining and IT industries Diane Isabelle, Kevin Horak, Sarah McKinnon \& Chiara Palumbo}

Kim, W.C., \& Mauborgne, R. 2005. Value innovation: a leap into the blue ocean. Journal of Business Strategy, 26(4): 22-28.

Kusi-Sarpong, S., Bai, C., Sarkis, J., \& Wang, X. 2015. Green supply chain practices evaluation in the mining industry using a joint rough sets and fuzzy TOPSIS methodology. Resources Policy, 46: 86-100.

Lakshmanan, V.I., Roy, R., \& Gorain, B. 2019. Case Study: Digital Disruption in the Mining Industry. In: Innovations and Breakthroughs in the Gold and Silver Industries, Springer, Cham: 199-241.

Lee, H., Kim, M.-S., \& Park, Y. 2012. An analytic network process approach to operationalization of five forces model. Applied Mathematical Modelling, 36(4): 17831795.

http://dx.doi.org/10.1016/j.apm.2011.09.012.

Legner, C., Eymann, T., Hess, T., Matt, C., ...\& Ahlemann, F. 2017. Digitalization: Opportunity and Challenge for the Business and Information Systems Engineering Community. Business \& Information Systems Engineering, 59: 301-308.

Madsen, T.K., \& Servais, P. 1997. The internationalization of born globals: an evolutionary process? International Business Review, 6(6): 561-583.

Maxfield, S. 2008. Reconciling Corporate Citizenship and Competitive Strategy: Insights from Economic Theory. Journal of Business Ethics, 80(2): 367-377. doi: $10.1007 / \mathrm{s} 10551-007-9425-1$

Narayanan, V.K., \& Fahey, L. 2005. The Relevance of the Institutional Underpinnings of Porter's Five Forces Framework to Emerging Economies: An Epistemological Analysis. Journal of Management Studies, 42(1): 207-223.

doi: 10.1111/j.1467-6486.2005.00494.X

Natural Resources Canada. 2020. The Canadian Minerals and Metals Plan.

https://www.nrcan.gc.ca/sites/www.nrcan.gc.ca/files /CMMP/CMMP_The_Plan-EN.pdf

Natural Resource Governance Institute. 2015. The Mining Industry - Overview and Trends. https://resourcegovernance.org/sites/default/files/d ocuments/nrgi_primer_mineral-industry.pdf

Neubert, M. 2017. Lean Internationalization: How to Globalize Early and Fast in a Small Economy. Technology Innovation Management Review, 7(5): 1622.

http://doi.org/10.22215/timreview/1073

Neubert, M. 2018. The Impact of Digitalization on the Speed of Internationalization of Lean Global Startups. Technology Innovation Management Review, 8(5): 4454.

http://doi.org/10.22215/timreview/1158

NRCan. 2019. Minerals and the economy. https://www.nrcan.gc.ca/our-naturalresources/minerals-mining/minerals-metalsfacts/minerals-and-economy/20529.

Oviatt, B.M. \& McDougall, P.P. 1994. Toward a theory of international new ventures. Journal of International Business Studies, 25(1): 45-64.

Oviatt, B.M., \& McDougall, P.P. 2005. The internationalization of entrepreneurship. Journal of International Business Studies, 36(1): 2-8.

Porter, M.E. 1979. How competitive forces shape strategy. Harvard Business Review, 57(2): 137-145.

Porter, M.E. 2008. The five competitive forces that shape strategy. Harvard Business Review, 86(1): 25-40.

PWC. 2019. Mine 2019 Resourcing the future. https://www.pwc.com/gx/en/energy-utilitiesmining/publications/pdf/pwc-mine-report-2019.pdf

Qi, C.C. 2020. Big data management in the mining industry. International Journal of Minerals, Metallurgy and Materials, 27(2): 131-139.

Rennie, M.W. 1993. Born global. The McKinsey Quarterly, 4: 45-53.

Slater, S.F., \& Olson, E.M. 2002. A fresh look at industry and market analysis. Business Horizons, 45(1):15-22. http:/ /dx.doi.org/10.1016/S0007-6813(02)80005-2

Statista. 2019. Mining - Statistics \& facts. https://www.statista.com/topics/1143/mining/

Thurlby, B. 1998. Competitive forces are also subject to change. Management Decision, 36(10): 19-24.

Visser, A.T., Thompson, R.J., \& Peroni, R. 2019. Application of New Technologies in Mining Industry to Low-Volume Roads. In: 12th International Conference on Low-Volume Roads, Kalispell, Montana, U.S.

Wahlström, B. 2019. Q\&A. What Can Action Research Learn from Business Environment Analysis?. Technology Innovation Management Review, 9(5): 7480. http://doi.org/10.22215/timreview/1242

Westerlund, M. 2019. The Emergence of Deepfake Technology: A Review. Technology Innovation Management Review, 9(11): 40-53.

Zucchella, A., Palamara, G., \& Denicolai, S. 2007. The drivers of the early internationalization of the firm. Journal of World Business, 42(3): 268-280. 


\section{Is Porter's Five Forces Framework Still Relevant? A study of the capital/labour intensity continuum via mining and IT industries Diane Isabelle, Kevin Horak, Sarah McKinnon \& Chiara Palumbo}

\begin{abstract}
About the Authors
Dr. Isabelle is an Associate Professor of International Business. Her research focuses broadly on the areas of science, innovation and techno-entrepreneurship within a global context. Specifically, her research is organized around the following three inter-related themes: 1) International entrepreneurship \& ecosystems, 2) Internationalization (International New Ventures and SMEs), 3) Global collaborative research and Science, Technology and Innovation policy. In addition to these themes, she is researching and publishing on Technologyintegrated and international interdisciplinary experiential learning in higher education. Prior to joining Sprott in 2011, Dr. Isabelle worked in several senior executive roles related to science, technology and industrial research (Industrial Research Assistance Program - IRAP) at the National Research Council of Canada (NRC), the Government of Canada's premier research and technology organization. She started her career as a project engineer for several multinational firms, including General Electric, Esso and Boeing Aerospace.
\end{abstract}

Kevin Horak, B. International Business, Carleton University, is a supply chain planner at MartinBrower of Canada Co. Fluent in Spanish, he spent a year abroad studying commerce and economics at the Universidad de Chile (Santiago).

Sarah McKinnon, B. International Business, Carleton University, is an Associate with Tailwind Associates, a Calgary-based firm dedicated to launching innovative entrepreneurs. She is inspired by the work ethic and tenacity of the entrepreneurial spirit and supports preparing small businesses for growth and investment. Previously, she worked at Sampford Advisors, a firm facilitating mergers and acquisitions for mid-market Canadian technology companies.

Chiara Palumbo is currently pursuing a Master of Science in Finance degree from Bocconi University, while working as Real Estate Investment Analyst for Italian company Generali Real Estate. She holds a Bachelor of Commerce (Finance) degree from Carleton University. Her past work experience includes investment banking at Lazard \& Co. in Debt Capital Markets and equity research for the Sprott Student Investment Fund.
Citation: Isabelle, D. 2020. Is Porter's Five Forces Framework Still Relevant? A study of the capital/labour intensity continuum via mining and IT industries. Technology Innovation Management Review, 10(6): 28-41. http://doi.org/10.22215/timreview/1366

Keywords: Porter's Five Forces framework, internationalization, mining industry, IT industry, regulation. 